\title{
De bedenktermijn doorgedacht
}

\author{
mr. dr. Hanneke Bennaars en mr. Anita van Empel*
}

\section{Inleiding}

De werknemer die heeft ingestemd met de beëindiging van zijn arbeidsovereenkomst is sinds 1 juli 2015 extra beschermd tegen al te lichtvaardige instemming. ${ }^{1}$ De geintroduceerde bedenktermijn van twee weken ${ }^{2}$ geeft hem de mogelijkheid zonder een reden op te geven een gesloten beëindigingsovereenkomst te ontbinden (artikel 7:670b lid $2 \mathrm{BW}$ ) of de instemming met een opzegging te herroepen (artikel 7:671 lid $2 \mathrm{BW}){ }^{3}$

Ook onder het oude recht werd al aangenomen dat aan de verklaring van de werknemer als het gaat om het accepteren van zijn ontslag hoge eisen moeten worden gesteld. De instemming van een werknemer met zijn ontslag moet duidelijk en ondubbelzinnig zijn en bovendien heeft de werkgever een zekere onderzoeksplicht. Hij moet nagaan of de werknemer de reikwijdte van zijn instemming voldoende heeft onderkend. ${ }^{4}$ De Hoge Raad maakt daarbij geen onderscheid tussen de situatie waarin de werknemer zelf ontslag neemt of berust in een gegeven ontslag (in beide gevallen eenzijdige rechtshandelingen) of het geval dat een beëindigingsovereenkomst

* Hanneke Bennaars is onderzoeker bij de leerstoelgroep arbeidsrecht \& socialezekerheidsrecht van de Universiteit van Amsterdam, Anita van Empel is Legal Manager Arbeidszaken bij ABN AMRO Bank NV.

1. Dit artikel is tot stand gekomen in het kader van een nog te verschijnen bundel van de werkgroep ontslagrecht van de Vereniging voor Arbeidsrecht. De auteurs danken de leden van de werkgroep voor hun kritische lezing van en nuttige aanvullingen op een eerdere versie.

2. Of drie weken als de werkgever de werknemer niet schriftelijk heeft gewezen op de bedenktermijn.

3. Meerdere auteurs hebben zich over de bedenktermijn gebogen. Zie onder meer: E.M. Hoogeveen, 'De opzegging met instemming, de beëindigingsovereenkomst en de bedenktermijn: nieuwe wegen vol valkuilen', ArbeidsRecht 2014/48, L.G. Verburg, 'Schikken in het nieuwe ontslagrecht: bedenk eer ge begint', ArA 2014 (13), S.F. Sagel, ‘De bedenkelijke bedenktermijn in Wetsvoorstel Werk en Zekerheid', TRA 2014/27, S.F. Sagel en O. van der Kind, 'Schikken in het neerdalend stof van de Wwz (I); de beëindigingsovereenkomst en de bedenktermijn', TRA 2016/86 en, recent, R. van Vliet, 'Het schriftelijkheidsvereiste van de beëindigingsovereenkomst: oude wijn in nieuwe zakken?', ArbeidsRecht 2017/8

4. Zie o.a. HR 17 januari 1969, NJ 1969/251 (Van der Tuuk/Pekela), HR 28 mei 1982, NJ 1983/2 (Coolwijk/Kroes), HR 14 januari 1983, NJ 1983/457 (Hajziani/Van Woerden), HR 15 april 1983, NJ 1983/458 (Hajjout/IJmah), HR 28 september 1984, NJ 1985/246 (Ben Dadi/ Mayonna), HR 25 maart 1994, JAR 1992/92 (Ritico/SMD), HR 19 april 1996, JAR 1996/116 (U-A-Sai/Harteveld), HR 19 september 2003, JAR 2003/244 (Marks/Albert Schweitzer) is gesloten. ${ }^{5}$ Onder het oude recht was de beëindiging met wederzijds goedvinden niet expliciet als wijze van beëindiging opgenomen in het systeem van het ontslagrecht. Op de beëindigingsovereenkomst, veelal met het karakter van een vaststellingsovereenkomst, was alleen het gewone vermogensrecht van toepassing, inclusief de leer van de wilsgebreken uit Boek 3 en Boek 6 BW. Onder het huidige recht kan de werknemer eenvoudig terugkomen op een eerdere instemming of op het sluiten van een beëindigingsovereenkomst. Bovendien geeft Titel 10 van Boek 7 nu een expliciet vormvoorschrift voor instemming met een opzegging en voor een beëindigingsovereenkomst: dat moet schriftelijk gebeuren. Een ontslagname kan nog wel steeds mondeling.

Deze nieuwe regels roepen een aantal vragen op. Prangend is de vraag wanneer de bedenktermijn begint te lopen. Anders gezegd: wanneer geldt de overeenkomst als 'tot stand gekomen'? De jurisprudentie is vooralsnog wisselend. Ook kan nog het een en ander worden gezegd over de consequenties van het inroepen van de bedenktermijn. Wat geldt bijvoorbeeld als de beëindigingsovereenkomst een ontslag op staande voet heeft vervangen omdat partijen de zaak hebben geregeld? Herleeft het ontslag op staande voet dan als de beëindigingsovereenkomst wordt ontbonden? In deze bijdrage onderzoeken de auteurs aan de hand van het arbeidsrecht en het algemeen vermogensrecht of een sluitend antwoord kan worden gevonden op deze vragen.

\section{Totstandkoming beëindigingsovereenkomst}

\subsection{Schriftelijkheid}

Als gezegd, introduceert de $\mathrm{Wwz}$ een vormvereiste voor de beëindigingsovereenkomst: deze moet schriftelijk worden aangegaan. Is nu in lijn met het oordeel van Rechtbank Den Haag ${ }^{6}$ een schriftelijke aanvaarding van een aanbod genoeg om te voldoen aan het schriftelijkheidsvereiste van artikel 7:670b lid $1 \mathrm{BW}$ of moet sprake zijn van ondertekening van een document, zoals Rechtbank Rotterdam heeft geoordeeld? ${ }^{7}$

5. Vgl. de analyse van de rechtspraak van de Hoge Raad door R.A.A. Duk, 'De Hoge Raad en het ontslag met wederzijds goedvinden', TRA 2012/34, par. 3 onderaan.

6. Ktr. Leiden 1 juni 2016, ECLI:NL:RBDHA:2016:8371. In gelijke zin inmiddels ook Ktr. Bergen op Zoom 15 februari 2017, ECLI:NL:RBZWB: 2017:1155

7. Ktr. Rotterdam 10 februari 2016, ECLI:NL:RBROT:2016:996. 
Rechtbank Den Haag overweegt onder meer dat 'het schriftelijkheidsvereiste van artikel $7: 670 \mathrm{~b} \mathrm{BW}$ niet zover gaat dat de bedenktermijn pas gaat lopen na ondertekening door partijen van de beëindigingsovereenkomst. Een zo vergaande afwijking van het reguliere contractenrecht en systeem van aanbod en aanvaarding zou, zo de wetgever dat heeft bedoeld, in de wet of in ieder geval in de wetsgeschiedenis zijn genoemd.' (r.o. 5.6).

Deze overweging geeft aanleiding dat reguliere contractenrecht eens onder de loep te nemen. De basis van het Nederlandse contractenrecht is het consensualisme en niet formalisme. ${ }^{8}$ Het sluiten van een overeenkomst is in beginsel vormvrij. Er is geen algemeen vormvoorschrift voor de wilsverklaring, die aan de basis van een rechtshandeling ligt (artikel 3:37 lid 1 BW). Op dit uitgangspunt bestaat echter een groot aantal uitzonderingen. Artikel 3:37 lid 1 BW laat immers de mogelijkheid open voor de wetgever (en voor partijen) om wel vormvoorschriften te verbinden aan rechtshandelingen ('[t]enzij anders is bepaald, (...)'). Schending van een wettelijk vormvoorschrift levert nietigheid op, tenzij de wet anders bepaalt (artikel 3:39 BW) of tenzij het voorschrift strekt ter bescherming van één der partijen. In dat geval ligt vernietigbaarheid eerder voor de hand als sanctie. ${ }^{9}$ In de regel zal een wettelijk vormvoorschrift inhouden dat een bepaalde rechtshandeling schriftelijk moet worden verricht, ${ }^{10}$ bij onderhandse akte ${ }^{11}$ of bij notariële akte. ${ }^{12}$ Over wat 'schriftelijk' inhoudt, wordt in Boek 3 niet veel geregeld. Artikel 3:37 lid 2 BW leert dat als bepaald is dat een verklaring schriftelijk moet worden gedaan, de verklaring ook bij exploit kan worden gedaan, maar dat brengt ons niet veel verder.

Het is bij de zoektocht naar de betekenis van 'schriftelijk' van belang de verschillende functies van schriftelijkheid in het overeenkomstenrecht te onderscheiden. Is sprake van een constitutief vereiste, of van een bewijsregel? Zie voor een voorbeeld van dat laatste de regel dat een verzekeringspolis schriftelijk moet zijn, artikel 7:932 BW: een verzekeringsovereenkomst kan dus geldig vormvrij gesloten worden, maar de schriftelijke polis is van belang als bewijsmiddel. ${ }^{13}$ De schriftelijkheidseis bij de beëindigingsovereenkomst is blijkens de redactie van

8. Rechtshandeling en overeenkomst (Van Dam), nr. 138, Deventer: Wolters Kluwer 2016.

9. Parlementaire Geschiedenis van het Nieuw Burgerlijk Wetboek, Deventer 1981 (Boek 3: Vermogensrecht in het algemeen) 3, p. 189. De gevolgen van schending van een contractueel vormvoorschrift wordt bepaald door de uitleg van de inhoud en strekking van de betreffende rechtshandeling, vlg. W. Snijders, 'Bekrachtiging en aanverwante rechtsfiguren', WPNR 6547 (2003) par. 9.

10. Zie bijvoorbeeld art. 6:267 lid 1 BW - een buitengerechtelijke ontbinding geschiedt door een schriftelijke verklaring.

11. Zie bijvoorbeeld art. 3:94 lid 1 BW - cessie geschiedt door een akte.

12. Zie bijvoorbeeld art. 3:260 lid 1 BW - het vestigen van een hypotheek gebeurt door een notariële akte.

13. Vgl. F.J. de Vries, De overeenkomst in het algemeen (Mon. BW nr. B54), Deventer: Wolters Kluwer 2016, nr. 91 (p. 143) en J.H. Wansink \& N. van Tiggele-van der Velde, T\&C Burgerlijk Wetboek, art. 7:932 BW, aant. 1. artikel 7:670b BW een constitutief vereiste: de overeenkomst is alleen geldig als zij schriftelijk is aangegaan.

Een volgend onderscheid dat gemaakt moet worden is het verschil tussen de eis van schriftelijkheid en de eis dat een overeenkomst in de vorm van een onderhandse akte moet worden vormgegeven. Met betrekking tot schriftelijkheid als constitutief vormvereiste heeft de wetgever in de parlementaire behandeling van de Aanpassingswet richtlijn inzake elektronische handel opgemerkt dat met een overeenkomst in 'schriftelijke vorm' in de zin van artikel 6:227a BW wordt bedoeld elke vorm van vastlegging van een overeenkomst in een geschrift. ${ }^{14}$ Geldt het vereiste van een onderhandse akte, dan moet sprake zijn van een door beide partijen ondertekend document, aldus artikel 156a lid $1 \mathrm{Rv}$. Geldt alleen de eis van schriftelijkheid, dan is een ondertekend document dus niet nodig. Dit onderscheid komt scherp terug in artikel 7:2 BW waarin de consumentenkoop van een onroerende zaak is geregeld. Het eerste lid bepaalt dat de overeenkomst schriftelijk moet worden aangegaan. Pas in het tweede lid, bij de regeling over de bedenktermijn, komt de akte om de hoek kijken. Loos heeft erop gewezen dat voor de totstandkoming van de koopovereenkomst geen akte nodig is, maar wel voor de start van de in het tweede lid geregelde bedenktermijn. ${ }^{15}$ In de evaluatie die Loos in zijn artikel bespreekt, wordt ook uiteengezet dat de term 'schriftelijk' niet met zich brengt dat een handtekening is vereist. De term schriftelijk laat ook ruimte om via een briefwisseling een overeenkomst te sluiten. Hiermee is 'schriftelijk' in lid 1 van artikel 7:2 BW niet consistent met het vereiste van een onderhandse akte in lid 2 van het tweede artikel. ${ }^{16} \mathrm{De}$ schrijvers van de evaluatie signaleren vervolgens dat het blijkens de wetsgeschiedenis ${ }^{17}$ wel de bedoeling is geweest dat de koopovereenkomst bij akte wordt gesloten en bevelen aan de terminologie in artikel 7:2 lid 1 $\mathrm{BW}$ (en ook overigens in artikel 7:766 BW) aan te passen.

Uit de tekst van artikel 7:670b lid $1 \mathrm{BW}$ blijkt niet dat sprake moet zijn van een onderhandse akte. Er staat slechts dat de overeenkomst schriftelijk moet worden aangegaan. Lid 2 bepaalt dat de bedenktermijn veertien dagen bedraagt na de datum waarom de overeenkomst tot stand is gekomen. Van belang is dus de vraag wanneer de overeenkomst tot stand is gekomen. In de volgende paragraaf gaan we in op de vraag van aanbod en aanvaarding. In deze paragraaf staat het schriftelijkheidsvereiste centraal. Net als ten aanzien van de regeling van artikel 7:2 BW werkt de parlementaire geschiedenis hier echter verwarrend. De regering heeft in de nota naar aanleiding van het verslag het volgende opgemerkt: 'Vanwege het grote belang van een werknemer bij een arbeidsrelatie is ervoor gekozen om werknemers

14. Kamerstukken // 2001/02, 28197, 3, p. 51.

15. M.B.M. Loos, 'Schriftelijkheidsvereiste en bedenktijd bij de koop van onroerende zaken', TBR 2010/101 onder 4.

16. A.L.M. Keirse e.a., Rapportage Wet op onroerende zaken; de evaluatie, Den Haag: Boom Juridische uitgevers, 2009, p. 41-42.

17. Kamerstukken I 2001/02, 23095, 38a, p. 5-6. 
die schriftelijk instemmen met een opzegging of die een beëindigingsovereenkomst ondertekenen een bedenktermijn van veertien dagen te gunnen om hierop terug te kunnen komen.'18 [onderstreping AHvE/JHB]. Deze zin in combinatie met de opmerking in de nota van wijziging dat voor de formulering is aangesloten bij artikel 7:653 lid $1 \mathrm{BW}^{19}$ heeft Rechtbank Rotterdam ${ }^{20}$ geleid tot het oordeel dat de datum van ondertekening van de overeenkomst leidend is voor het totstandkomingsmoment. De rechtbank lijkt daarmee het zwaardere vereiste van de onderhandse akte aan te nemen.

Wij betwijfelen of de wetsgeschiedenis tot die conclusie kan leiden. In de eerste plaats mag van de wetgever worden verwacht dat een vormvereiste, dat toch doorgaans (mede) tot doel heeft de rechtszekerheid te vergroten, eenduidig wordt geformuleerd. Het in de wettekst opnemen van de bewoording 'akte' is geenszins bezwaarlijk. Als dat bedoeld is, had dat dus moeten worden opgeschreven. Een ander argument waarom minder waarde gehecht zou moeten worden aan het citaat uit de parlementaire geschiedenis is dat de regering in het desbetreffende fragment reageert op vragen van een aantal fracties naar de reden en duur van de geintroduceerde bedenktermijn en naar de mogelijkheid van misbruik (het stapelen van herroepingen/ontbindingen). De vragen zijn gesteld naar aanleiding van het oorspronkelijke wetsvoorstel waarin het schriftelijkheidsvereiste nog niet was opgenomen. ${ }^{21}$ De regering antwoordt onzes inziens meer in algemene zin en bedoelt veeleer 'een beëindigingsovereenkomst aangaan' dan 'ondertekenen'. Pas in de volgende alinea schrijft de regering dat zij aanleiding ziet te bepalen dat de beëindigingsovereenkomst schriftelijk moet zijn. De regering volgt hierbij expliciet de suggestie van Sagel, zo blijkt uit de parlementaire behandeling in de Eerste Kamer. ${ }^{22}$ Sagel $^{23}$ heeft gepleit voor een schriftelijkheidseis omdat naar zijn oordeel de voorgestelde regeling anders niet zou werken, daar waar zij wel nuttig kan zijn. ${ }^{24}$ Het gaat hem om die gevallen waarin een werknemer wellicht onder enige druk van de werkgever en zonder rechtsbijstand akkoord is gegaan met een ontslag. Juist in die gevallen waarin een informatietekort bij de werknemer bestaat, zal de bedenktermijn ook niet snel bekend zijn. Dus voor een nuttig effect is schriftelijkheid nodig. De overeenkomst moet schriftelijk worden aangegaan, maar vooral, zo begrijpen wij Sagel, moet er een schriftelijke verwijzing naar de bedenktermijn zijn. De wetgever heeft deze suggestie overgenomen, maar nergens geëxpliciteerd (en Sagel doet dat ook niet) dat sprake moet zijn van een onder-

18. Kamerstukken // 2013/14, 33818, 7, p. 56.

19. Kamerstukken I/ 2013/14, 33818, 8, p. 17.

20. Ktr. Rotterdam 10 februari 2016, ECLI:NL:RBROT:2016:996, r.o. 5.4.

21. Kamerstukken I/ 2013/14, 33818, 2, p. 10.

22. Kamerstukken / 2013/14, 33818, C, p. 47.

23. S.F. Sagel, 'De bedenkelijke bedenktermijn in Wetsvoorstel Werk en Zekerheid', TRA 2014/27.

24. Sagel tekent aan dat hij inschat dat die situatie niet vaak aan de orde zal zijn, maar voor die gevallen zou de regeling beter moeten worden vormgegeven. handse akte. ${ }^{25}$ Het gaat onzes inziens te ver om het vormvereiste, op basis van een fragment uit de wetsgeschiedenis, strenger te maken dan uit de letterlijke tekst volgt. Hierbij speelt een rol dat een vormvereiste een uitzondering is op de hoofdregel dat overeenkomsten vormvrij zijn. Reden te meer om niet al te extensief uit te leggen.

Het eerste argument van Rechtbank Rotterdam is daarmee niet overtuigend. Blijft over de verwijzing naar artikel 7:653 BW. Dat argument gaat over de ratio van de schriftelijkheidseis en dus niet per se over de ratio van de bedenktermijn. Schriftelijkheid als vormvereiste dient het algemeen belang van de rechtszekerheid en in voorkomend geval het belang van één der partijen, te weten bescherming tegen een informatietekort of tegen een overhaaste beslissing. Verburg heeft er eerder al op gewezen dat de wetgever als het gaat om het schriftelijkheidsvereiste in het arbeidsrecht steevast in het midden laat hoe aan dat schriftelijkheidsvereiste voldaan moet worden. ${ }^{26}$ De verschillende bijzondere bedingen (wijzigingsbeding, proeftijdbeding, boetebeding, concurrentiebeding en uitzendbeding) hebben allemaal een andere formulering van het schriftelijkheidsvereiste. ${ }^{27}$ Verburg stelt zich op het standpunt dat ondertekening niet, althans niet altijd, noodzakelijk is en sluit ter onderbouwing daarvan aan bij artikel 6:227a BW (waarover later meer). Het concurrentiebeding neemt tussen al die bedingen een bijzondere plaats in. Verburg wijst erop dat het schriftelijkheidsvereiste bij het concurrentiebeding niet alleen de rechtszekerheid en de kenbaarheid dient, maar ook een waarborgfunctie heeft. ${ }^{28}$ De waarborgfunctie houdt in dat de werknemer de consequenties van het aangaan van het concurrentiebeding en de daaraan verbonden consequenties goed heeft moeten kunnen overwegen. ${ }^{29}$ Het is in dat licht ${ }^{30}$ dat de verdere jurisprudentie over wanneer aan het schriftelijkheids-

25. Het is heel wel mogelijk dat zowel Sagel als de wetgever een overeenkomst in de vorm van een onderhandse akte voor ogen hadden, zeker gelet op de bestaande praktijk waarin dit toch in de meeste gevallen aan de orde zal zijn, maar dat is toch wel een erg magere basis voor het aannemen van een ander, strenger, vormvereiste dan de letterlijk tekst van de wet voorschrijft.

26. L.G. Verburg, 'Het beding van artikel 7:613 BW: toepassingsgebied, de relatieve zwaarte van de "613"-maatstaf en het vereisten van schriftelijkheid', ArA 2012 (11) 1, p. 39. Zie hierover al eerder E. Verhulp in zijn annotatie bij HR 28 maart 2008, NJ 2008/503 (Philips/Oostendorp), par. 5.

27. 'Schriftelijk beding', 'schriftelijk aangegaan', 'schriftelijk overeengekomen', 'schriftelijk bedongen'.

28. Zie ook F.B.J.G. Grapperhaus, Werknemersconcurrentie, (dissertatie) Deventer: Kluwer 1995, p. 208 die zich baseert op oudere rechtspraak en literatuur en I.P. Asscher-Vonk, 'Bijzondere bedingen', ArA 2004/3, p. 17 die Grapperhaus aanhaalt. Ook Houweling heeft zich in gelijke zin uitgelaten: A.R.Houweling, 'Het schriftelijkheidsvereiste bij het concurrentiebeding ex artikel 7:653 BW anno 2006', ArA 2006/2, p. 67-69, alsook in zijn bijdrage 'Schriftelijke bedingen in het arbeidsrecht en de noodzakelijke devaluatie van het schriftelijkheidsvereiste' in Even e.a. (red.), Arbeidsrechtelijke bedingen. Themabundel Tijdschrift Arbeidsrechtpraktijk 2012, Den Haag: Sdu Uitgevers 2012.

29. I.P. Asscher-Vonk, 'Bijzondere bedingen', ArA 2004/3, p. 17.

30. Naast het persoonlijke karakter dat met zich brengt dat een concurrentiebeding niet in een cao kan worden opgenomen, Kamerstukken II 1993/94, 23438, 3, p. 35. 
vereiste ex artikel 7:653 $\mathrm{BW}$ is voldaan zich heeft ontwikkeld. In het arrest Philips/Oostendorp ${ }^{31}$ heeft de Hoge Raad de waarborgfunctie nogmaals benadrukt en geoordeeld dat aan het schriftelijkheidsvereiste in ieder geval is voldaan als het concurrentiebeding is opgenomen in een arbeidsovereenkomst of ander geschrift dat door de werknemer is ondertekend. Ook een ondertekende arbeidsovereenkomst waarin verwezen wordt naar bijgevoegde arbeidsvoorwaarden waarin een concurrentiebeding voorkomt, volstaat, aldus de Hoge Raad in r.o. 3.4. Niet is voldaan aan het schriftelijkheidsvereiste als een werknemer zich schriftelijk akkoord verklaart met de inhoud van een niet als bijlage bijgevoegd document waarin een concurrentiebeding voorkomt, tenzij de werknemer daarbij uitdrukkelijk verklaart dat hij met het concurrentiebeding instemt (nog steeds r.o. 3.4).

Wij menen in de eerste plaats dat de woorden 'in ieder geval' de mogelijkheid openlaten dat ook in andere gevallen voldaan kan zijn aan het schriftelijkheidsvereiste. ${ }^{32}$ Daarnaast zou bij het oordeel over het schriftelijkheidsvereiste in artikel 7:670b BW het volgende in aanmerking moeten worden genomen. De waarborgfunctie bij het aangaan van het concurrentiebeding is vormgegeven in het schriftelijkheidsvereiste. De waarborgfunctie bij het aangaan van de beëindigingsovereenkomst is grotendeels gelegen in de bedenktermijn zelf. De werknemer wordt een termijn gegund waarin hij zich van rechtsbijstand kan voorzien en zich (achteraf) kan bezinnen op zijn keuze. De werkgever heeft een (schriftelijke) meldingsplicht ten aanzien van de bedenktermijn met als sanctie verlenging van de termijn. Niet valt in te zien, mede gelet op de omstandigheid dat de wetgever niet heeft gekozen voor de onderhandse akte als vormvereiste, waarom de schriftelijkheidseis zo ver gaat dat daaraan alleen is voldaan als sprake is van een ondertekende overeenkomst (dus een onderhandse akte). Wij zijn met Rechtbank Den Haag van oordeel dat ook een briefwisseling (al dan niet tussen gemachtigden) waaruit voldoende blijkt dat sprake is van een aanbod en aanvaarding de totstandkoming van de beëindigingsovereenkomst tot gevolg heeft. Kortom, ook de verwijzing naar artikel 7:653 BW overtuigt niet. Ook Sagel en Van der Kind komen tot die conclusie in hun analyse van het schikkingsproces na de $\mathrm{Wwz}^{33}$

In de zaak die ten grondslag lag aan de uitspraak van Rechtbank Den Haag was sprake van een e-mailcorrespondentie tussen gemachtigden. Kan onder 'schriftelijk overeenkomen' in de zin van artikel 7:670b BW ook worden verstaan 'per e-mail'? Een vraag die in dit tijdsgewricht waarin ook per WhatsApp kan worden aange-

31. HR 28 maart 2008, JAR 2008/113 (Philips/Oostendorp).

32. Zie bijvoorbeeld de voorbeelden die A-G Verkade in zijn conclusie voor Philips/Oostendorp noemt, waaronder een briefwisseling waarin de werknemer zich akkoord verklaart met het concurrentiebeding (overweging 4.9.6 en 4.9.7).

33. S.F. Sagel \& O. van der Kind, 'Schikken in het neerdalend stof van de WWz (I); de beëindigingsovereenkomst en de bedenktermijn', TRA 2016/86, p. 50 I.k. $\operatorname{zegd}^{34}$ wellicht wat archaïsch aandoet, maar toch enige aandacht verdient. In artikel $6: 227 \mathrm{a} \mathrm{BW}$ is geregeld dat indien uit de wet voortvloeit dat een overeenkomst slechts in schriftelijke vorm geldig en onaantastbaar tot stand kan komen, aan dit vormvereiste is voldaan als de overeenkomst langs elektronische weg is gesloten. Lid 1 somt op aan welke voorwaarden voldaan moet zijn: (1) de elektronische overeenkomst moet door partijen raadpleegbaar zijn, (2) de authenticiteit van de overeenkomst moet in voldoende mate gewaarborgd zijn, (3) het moment van totstandkoming van de overeenkomst moet met voldoende zekerheid kunnen worden vastgesteld en (4) de identiteit van partijen moet met voldoende zekerheid kunnen worden vastgesteld. ${ }^{35}$ Voor de laatste twee vereisten geldt blijkens de memorie van toelichting dat hierover met name twijfel kan bestaan als via internet een overeenkomst wordt gesloten. Wordt op een andere wijze elektronisch een overeenkomst gesloten, dan is het de bedoeling dat voor de invulling van 'met voldoende zekerheid' aansluiting wordt gezocht bij het papieren rechtsverkeer. Er moet als elektronisch wordt gecontracteerd een gelijke mate van zekerheid bestaan als bij contracteren op papier. ${ }^{36}$ Wordt bijvoorbeeld beoogd via e-mail een overeenkomst tot stand te doen komen waarvoor de wet de schriftelijke vorm voorschrijft, dan zal wat betreft de voorwaarde genoemd onder 3 doorgaans voldoende zijn dat vastgesteld kan worden op welk tijdstip de aanbieder de aanvaarding ontvangen heeft, omdat daarmee in het normale geval het moment van totstandkoming vaststaat. ${ }^{37} \mathrm{Via}$ de schakelbepaling van artikel 6:216 $\mathrm{BW}$ is dit artikel ook van toepassing op artikel 7:670b lid $1 \mathrm{BW}$. In de arbeidsrechtelijke ontslagpraktijk wordt zelden een probleem gemaakt van de elektronische component bij het via e-mail bereiken van overeenstemming over een beëindigingsregeling. Wij zouden, net als Rechtbank Den Haag, menen dat een aanvaarding per e-mail geldt als totstandkomingsmoment van de overeenkomst (mits aan alle vereisten van aanbod en aanvaarding is voldaan). Een elektronisch document, voorzien van elektronische handtekeningen als bedoeld in artikel 3:15a BW, volstaat uiteraard ook. $\mathrm{Er}$ is dan sprake van een elektronische onderhandse akte. Zoals eerder betoogd, vinden wij dat niet noodzakelijk om te voldoen aan het schriftelijkheidsvereiste. Deze opvatting sluit aan bij de wijze waarop de Centrale Raad van Beroep beoordeelt wanneer sprake is van een

34. Ktr. Amsterdam 10 juni 2015, ECLI:NL:RBAMS:2015:3968.

35. Deze opsomming geeft aan in welke gevallen bedoelde gelijkstelling in ieder geval plaatsvindt. Het is niet ondenkbaar dat de rechter, afhankelijk van de strekking van het wettelijke vormvoorschrift, in een concreet geval tot de conclusie komt dat de gelijkstelling op zijn plaats is, ook al is niet aan alle vier genoemde voorwaarden voldaan, Valk, T\&C Burgerlijk Wetboek, art. 6:227a, aant. 2 onder c en de verwijzingen aldaar naar de parlementaire geschiedenis. Wij merken op dat deze ruime uitleg blijkens de wetsgeschiedenis vooral geldt als de schriftelijkheidseis uitsluitend is gesteld met het oog op de bewijsbaarheid. In het geval van de beëindigingsovereenkomst is sprake van een constitutief vereiste, niet van een bewijsvoorschrift.

36. Kamerstukken I/ 2001/02, 28197, 3, p. 52.

37. Kamerstukken II 2001/02, 28197, 3, p. 54. 
tot stand gekomen beëindigingsovereenkomst in het kader van de fictieve opzegtermijn. ${ }^{38}$

\subsection{Aanbod en aanvaarding}

Artikel 6:217 BW bepaalt dat een overeenkomst tot stand komt door aanbod en aanvaarding. Artikel 6:227 BW schrijft vervolgens voor dat overeenkomsten die partijen aangaan bepaalbaar moeten zijn. Dit betekent dat ook het aanbod daartoe voldoende concreet dient te zijn. Het zal álle essentiële elementen moeten bevatten, en soms zelfs meer. Zo'n aanbod wordt ook wel een 'volledig aanbod' genoemd. In tegenstelling tot een 'onvolledig aanbod', dat in feite niet meer is dan een aan een ander gerichte uitnodiging tot het doen van een aanbod. Soms kan een aanbod wel alle essentiële elementen bevatten, maar komt bij de aanvaarding daarvan toch geen overeenkomst tot stand. Dit speelt bijvoorbeeld bij zaken die op Marktplaats te koop worden aangeboden, bij een huis dat via een advertentie te koop wordt gezet, of bij een vacature die wordt geplaatst. Hier geldt dat hoewel het om een individueel bepaalde zaak gaat, de mededeling niet tot een bepaalde persoon is gericht en dat maakt dat in die gevallen de aanvaarding niet (direct) tot een overeenkomst leidt.

Aanbod en aanvaarding om tot het einde van de arbeidsovereenkomst te komen kan op verschillende manieren. De werkgever kan in een gesprek een aanbod doen, in een brief of e-mail, of via een advocaat. Een aanbod kan volledig gespecificeerd zijn (bijvoorbeeld doordat een concept-vaststellingsovereenkomst is bijgevoegd) of eerder een open uitnodiging zijn om in onderhandeling te treden: 'een vertrek is voor ons bespreekbaar'. De uiteindelijke maatstaf om te bepalen of een overeenkomst tot stand is gekomen is of partijen (erop hebben mogen vertrouwen dat zij) wilsovereenstemming hebben bereikt. ${ }^{39}$ Dat er overeenstemming is over essentialia kan betekenen dat er een overeenkomst is, maar dat hoeft niet het geval te zijn. Als het de bedoeling van partijen is om ten aanzien van al hun geschilpunten overeenstemming te bereiken, hetgeen bij het aangaan van een vaststellingsovereenkomst doorgaans aan de orde zal zijn, is overeenstemming over essentialia niet voldoende. ${ }^{40}$ Als essentialia worden doorgaans beschouwd het einde van het dienstverband als zodanig, het tijdstip van de beëindiging en het wel of niet toekennen van een vergoeding in het kader van de beëindiging. ${ }^{41}$

38. Vgl. CRvB 17 november 2010, RSV 2011/95, ro. 4.3; CRvB 7 november 2012, ECLI:NL:CRVB:2012:BY2391, r.o. 4.3.en CRvB 6 november 2013, USZ 2013/366, r.o. 5.3

39. Y.G. Blei Weissmann, GS Verbintenissenrecht, art. 6:217 BW, aant. 2.3 en ook A-G. Wissink in zijn conclusie voor HR 8 juli 2011, JAR 2011/211 (Scharffenorth/Nederlands-Duitse Handelskamer), overweging 2.4 .

40. Vgl. HR 8 juli 2011, JAR 2011/211 (Scharffenorth/Nederlands-Duitse Handelskamer). De Hoge Raad laat (onder verwijzing naar art. 81 RO) het arrest van Hof Den Haag 8 september 2009, JAR 2009/269 waarin langs die lijn is geoordeeld, in stand.

41. F.B.J. Grapperhaus e.a. (red.), Afvloeiingsregelingen in het arbeidsrecht, Deventer: Kluwer 2004, p. 164.
In die zin lijkt bij een beëindigingsovereenkomst de toets wat strenger dan bij de vraag of een arbeidsovereenkomst tot stand is gekomen, zo blijkt uit het TomTom-arrest. ${ }^{42}$ Daar was sneller dan gedacht sprake van een aanvaard aanbod. Hof Amsterdam heeft in deze zaak bepaald dat (ook) in het geval er enkel overeenstemming wordt bereikt over een vóórovereenkomst (een 'termsheet') waarin de hoofdlijnen/essentialia waren opgenomen, de arbeidsovereenkomst tot stand is gekomen, ondanks dat er nog een aantal bijzondere bedingen (nonconcurrentie, geheimhouding, intellectuele eigendom) moesten worden uitgewerkt en ondanks dat er over de definitieve arbeidsovereenkomst uiteindelijk geen wilsovereenstemming is bereikt. Hierbij is ook veel waarde gehecht aan het feit dat partijen ook al uitvoering zijn gaan geven aan de afspraken.

Een bijzondere variant van een aanbod tot beëindiging van de arbeidsovereenkomst is een collectief aanbod, bijvoorbeeld via een sociaal plan, dat aan een groep medewerkers wordt gedaan. Zo'n aanbod kan, omdat werkgever en werknemer geen vreemden voor elkaar zijn en de mededeling - hoewel collectief gedaan - toch tot een persoon gericht is, wel worden gezien als volledig aanbod. ${ }^{43}$

Is er een volledig en daarmee ook bindend aanbod, dan komt door de enkele anvaarding van dat aanbod de overeenkomst tot stand, zie artikel 6:217 lid 1 BW. Die aanvaarding dient onvoorwaardelijk te zijn: diegene die het aanbod aanvaardt, dient met alle elementen van het aanbod in te stemmen. Tot 1 juli 2015 gold op basis van het algemeen verbintenissenrecht dat de beëindiging van de arbeidsovereenkomst vormvrij kon worden overeengekomen, waarbij volgens vaste jurisprudentie ${ }^{44}$ wel rekening werd gehouden met de niet gelijkwaardige positie van de werknemer ten opzichte van de werkgever. Nu moet dat schriftelijk, zie de vorige paragraaf. De werknemer diende en dient overigens nog steeds 'duidelijk en ondubbelzinnig' in te stemmen met de beëindiging van zijn dienstverband. De werkgever heeft op dit punt ook een onderzoeksplicht. Hij mag er niet te snel en te makkelijk van uitgaan dat die instemming er is.

Het blijft naar ons oordeel ook in het Wwz-tijdperk mogelijk om bij een collectief vertrekvoorstel zonder beëindigingovereenkomst in de vorm van een ondertekende akte de arbeidsovereenkomst te laten eindigen, indien daarbij maar aan (de functies van) het schriftelijkheidsvereiste wordt voldaan:

1. kenbaarheid: omdat sociale plannen doorgaans in een cao worden neergelegd, die voor medewerkers over het algemeen makkelijk te raadplegen is, terwijl daaromheen doorgaans ook nog veel berichtgeving plaatsvindt, zou dit geen probleem moeten geven;

42. Hof Amsterdam 16 maart 2010, JAR 2010/178, bekrachtigd in HR 9 december 2011, ECLI:NL:HR:2011:BT6408, JAR 2012/16.

43. Conclusie bij HR 1 april 2011, JAR 2011/110 (Turkenburg/ABN AMRO).

44. Zie de jurisprudentie genoemd in paragraaf 1. 
2. rechtszekerheid: lijkt evenmin een probleem op te leveren bij een sociaal plan; rechten, verplichtingen en de consequenties van het accepteren van het aanbod staan immers uitgebreid omschreven en mocht een werknemer menen dat hij tekort wordt gedaan of een andere lezing van een bepaling uit dat sociaal plan hebben, dan kan hij dat altijd aan een rechter of arbitragecommissie voorleggen, en

3. de waarborgfunctie: hier zou evenmin een probleem moeten ontstaan nu een sociaal plan doorgaans met vakbonden (professionele vertegenwoordigers van werknemers) is uitonderhandeld.

\subsection{Andere bedenktermijnen}

Om de vraag te beantwoorden wanneer sprake is van de start van een bedenktermijn, is het ten slotte nuttig om te kijken naar andere bedenktermijnen in het algemeen verbintenissenrecht. Er bestaan verschillende bedenktermijnen. ${ }^{45}$ Het valt op dat doorgaans wordt gekozen voor een heel precies geformuleerd moment waarop de bedenktermijn gaat lopen. Dat moment is niet altijd gekoppeld aan het moment waarop de overeenkomst tot stand is gekomen/het aanbod is aanvaard.

- $\quad$ Koop van onroerende zaken (artikel 7:2 BW)

Kennelijk vindt de wetgever de aankoop van een onroerende zaak zo ingrijpend dat hij de consument-koper de meeste vergaande bescherming wil bieden. Voor de start van deze bedenktermijn is angesloten bij het ondertekenen van de akte (zie lid 2). De wetgever hecht eraan

het moment waarop de bedenktermijn een aanvang neemt, duidelijk vast te leggen. ${ }^{46}$ De koper heeft vervolgens gedurende drie dagen het recht de koop te ontbinden. Die ontbinding is vormvrij. ${ }^{47}$ Dit recht ontstaat niet opnieuw in het geval de koper eenmaal van het ontbindingsrecht gebruik heeft gemaakt en binnen zes maanden met dezelfde verkoper en dezelfde zaak een nieuwe koopovereenkomst sluit. Zie hier de parallel met het ontslagrecht, waarvoor ook geldt dat de werknemer zich niet voor een tweede maal op het bedenkrecht kan beroepen als hij dat in de zes maanden daaraan voorafgaand al eerder heeft gedaan (artikel 7:670b lid 4 BW).

\section{- $\quad$ Koop op afstand (artikel 6:230o BW)}

Bij koop op afstand komt de overeenkomst tot stand wanneer de consument het aanbod accepteert. ${ }^{48}$ De consument heeft na ontvangst van de zaak veertien dagen het recht om de koop zonder opgaaf van redenen te ontbinden. De achterliggende gedachte van deze ontbindingsbevoegdheid is tweeërlei: tijdens deze termijn kan de consument de gekochte zaak inspecteren en hij kan de termijn gebruiken om over zijn ankoop na te den-

45. Zie ook S.F. Sagel, De bedenkelijke bedenktermijn in Wetsvoorstel wet werk en zekerheid', TRA 2014/27.

46. A.G. Castermans en H.B. Krans, Tekst \& Commentaar, art. 7:2 BW aant. 2, met verwijzing naar Kamerstukken II 1995/96, 23095, 5, p. 8.

47. A.G. Castermans en H.B. Krans, Tekst \& Commentaar, art. 7:2 BW, aant. 3, met verwijzing naar Kamerstukken II 1995/96, 23095, 5, p. 10, waarbij wordt opgemerkt dat partijen ter zake vormvoorschriften kunnen overeenkomen, tenzij de bevoegdheid praktisch niet meer valt uit te oefenen.

48. J.W Rutgers, Tekst \& Commentaar, art. 6:230g BW, aant. 2. ken, zeker in het geval hij zich overrompeld of psychisch onder druk gezet heeft gevoeld. ${ }^{49} \mathrm{Als}$ de verkoper de koper niet wijst op de ontbindingsmogelijkheid (artikel 6:230m lid 1 onderdeel h BW), dan kan de termijn waarin de koper zich kan bedenken zelfs worden opgerekt tot maximaal twaalf maanden. Ook hier geldt, evenals bij de beëindiging van de arbeidsovereenkomst, de verplichting dat de aanvaardende (onderliggende) partij wordt gewezen op de bedenktermijn, op straffe van een verlenging van die termijn. De ontbinding van de overeenkomst bij koop op afstand is vormvrij, maar dient wel ondubbelzinnig te zijn (artikel 6:230o lid $3 \mathrm{BW}$ ).

- Vakantieproducten van lange duur (artikel 7:50a $B W$ en artikel 7:50d $B W$ )

$\mathrm{Bij}$ het aangaan van een overeenkomst voor (gebruik van) een vakantieproduct voor lange duur geldt een herroepingsrecht van de consument van veertien dagen, te rekenen vanaf de dag van sluiting van de (voor)overeenkomst of vanaf de dag waarop de consument het afschrift van die overeenkomst ontvangt als die dag later valt. Net als bij de ontbinding van de beëindigingsovereenkomst geldt hier dat ontbinding van de overeenkomst tot stand komt door een schriftelijke verklaring, zonder dat daarbij een reden hoeft te worden opgegeven. Als de handelaar de consument niet op zijn bedenktermijn wijst, wordt die termijn (net als bij de beëindiging van de arbeidsovereenkomst) verlengd (tot maximaal drie maanden).

\subsection{Tussenconclusie}

Wij komen tot de conclusie dat de bedenktermijn aanvangt op het moment dat partijen schriftelijk overeenstemming hebben bereikt over de beëindigingsovereenkomst. Dat hoeft niet te zijn het moment waarop partijen een akte hebben ondertekend, maar dat kan ook wanneer een (schriftelijk) aanbod schriftelijk is anvaard. Dat kan zowel in papieren correspondentie als in e-mailcorrespondentie.

De vraag is nog wat rechtens is als bijvoorbeeld via (e-mail)correspondentie op datum $\mathrm{X}$ overeenstemming is bereikt en de beëindigingsovereenkomst wordt ondertekend op datum $\mathrm{Y}$ en in de beëindigingsovereenkomst is opgenomen dat de bedenktermijn begint te lopen na ondertekening door de werknemer van de vaststellingsovereenkomst. In dat geval wordt in feite een langere bedenktermijn overeengekomen dan de wettelijke bedenktermijn. Hoewel artikel 7:670b lid 2 BW van dwingend recht is, menen wij dat een afwijking ten gunste van de werknemer hier niet nietig is, maar op grond van artikel 3:40 lid $2 \mathrm{BW}$ vernietigbaar. De bedenktermijn strekt immers tot bescherming van één der partijen, de werknemer. Wel is het in het geschetste geval zo dat de overeenkomst nog steeds tot stand gekomen is op het moment van aanvaarding, maar dat slechts de bedenktermijn op een ander, later, moment is angevangen.

49. J.W Rutgers, Tekst \& Commentaar, art. 6:230g BW, aant. 1. 
Uit de analyse van andere bedenktermijnen blijkt dat de wetgever daar doorgaans heeft gekozen voor een duidelijker bepaald moment waarop de bedenktermijn begint te lopen. Het zou onzes inziens voor de rechtspraktijk eenvoudiger zijn geweest wanneer de wetgever ook in artikel 7:670b lid $1 \mathrm{BW}$ ondubbelzinnig het vormvereiste van de onderhandse akte had opgenomen, of een ander duidelijk moment had aangewezen waarop de bedenktermijn begint te lopen in plaats van het algemene 'de datum waarop de overeenkomst tot stand is gekomen'.

\section{Gevolgen van de ontbinding}

\subsection{Inleiding}

In deze paragraaf behandelen we een aantal vragen die aan de orde komen als de werknemer gedurende de bedenktermijn de beëindigingsovereenkomst ontbindt. Op grond van artikel 6:271 $\mathrm{BW}$ geldt dan dat partijen bevrijd zijn van de verbintenissen uit de overeenkomst. Voor zover verbintenissen al zijn nagekomen ontstaat een verbintenis tot ongedaanmaking. Sluit de aard van de prestatie uit dat zij ongedaan wordt gemaakt dan treedt daarvoor een vergoeding in de plaats, aldus artikel 6:272 lid $1 \mathrm{BW}$. In de regel zal gedurende de bedenktermijn nog geen uitvoering worden gegeven aan de overeenkomst. Wel kan worden gedacht aan een vrijstelling van werk die onmiddellijk ingaat. Ontbindt de werknemer, dan is het de vraag of de werkgever een vergoeding toekomt omdat de werknemer nu eenmaal niet achteraf alsnog kan werken. Wij zouden menen van niet. De werkgever heeft door vrijstelling van werkzaamheden onmiddellijk overeen te komen in de wetenschap dat er een bedenktermijn is, het risico genomen dat de werknemer achteraf ten onrechte niet heeft gewerkt. ${ }^{50}$ Ook denkbaar is dat in de beëindigingovereenkomst is opgenomen dat indien de werknemer de overeenkomst ontbindt de dagen waarop hij vrijgesteld van werk is geweest als vakantiedagen hebben te gelden. Het is de vraag of dat een te grote belemmering vormt voor het gebruik kunnen maken van de bedenktermijn. Wij menen dat dat niet het geval is, gelet op de hiervoor geschetste risicoverdeling.

Een volgende vraag is of de werknemer de beëindigingovereenkomst door een verklaring per e-mail kan ontbinden. Het eerder besproken artikel 6:227a BW is beperkt tot overeenkomsten en strekt zich niet uit tot alle rechtshandelingen. In sommige bepalingen wordt artikel 6:227a BW wel van toepassing verklaard. Relevant voor de bedenktermijn is artikel 6:267 lid $1 \mathrm{BW}$ waarin staat dat de buitengerechtelijke ontbinding (waaronder ook begrepen de ontbinding zoals geregeld

50. Zie in vergelijkbare zin over een iets andere casus: L.G. Verburg, 'Schikken in het nieuwe ontslagrecht: bedenk eer ge begint', ArA 2014 (13) 2, p. 8. Eveneens in vergelijkbare zin G.C. Boot e.a. (red.), Arbeidsprocesrecht inclusief Wet werk en zekerheid, Deventer: Kluwer 2015, p. 20. in artikel 7:670b lid 2 BW) ook kan worden gedaan door een verklaring langs elektronische weg. De voorwaarde is dan wel dat de overeenkomst langs elektronische weg is gesloten. Hier zou a contrario uit kunnen worden afgeleid dat als de overeenkomst op papier is gesloten, een ontbindingsverklaring alleen op papier kan worden gedaan. Dit zou niet bepaald in lijn zijn met de praktijk. Evenmin valt in te zien wat het bezwaar is tegen een ontbinding per e-mail, zeker als partijen eerder per e-mail hebben gecorrespondeerd. ${ }^{51}$ Dit geldt temeer nu aan het schriftelijkheidsvereiste van de aanzegging uit artikel 7:668 lid $1 \mathrm{BW}$ is voldaan indien per WhatsApp is aangezegd, zoals Rechtbank Den Haag oordeelt. ${ }^{52}$

In de volgende paragrafen bekijken we een tweetal casusposities waarin vragen omtrent de gevolgen van de ontbinding aan de orde komen nader.

\subsection{Casus 1}

Een bekende praktijksituatie is dat een werknemer op staande voet wordt ontslagen en werkgever en werknemer uiteindelijk een beëindigingsovereenkomst sluiten waarbij het ontslag op staande voet wordt ingetrokken en partijen met wederzijds goedvinden uit elkaar gaan. Op de beëindigingsovereenkomst is - uiteraard - de wettelijke bedenktermijn van toepassing. Wat nu als de werknemer (al dan niet op de laatst mogelijke dag) de beëindigingsovereenkomst ontbindt, terwijl het ontslag op staande voet is ingetrokken? Staat de werkgever dan met lege handen of niet? De intrekking van het ontslag op staande voet moet in overeenstemming met de werknemer gebeuren. De werkgever kan immers niet eenzijdig de opzegging intrekken. ${ }^{53}$ Staat de intrekking van het ontslag op staande voet in de beëindigingsovereenkomst, dan leidt de ontbinding van de gehele overeenkomst ertoe dat een ongedaanmakingsverplichting ontstaat. De werkgever zal naar ons idee in dat geval via een verklaring de intrekking van de opzegging moeten herroepen. De beëindigingsovereenkomst wordt immers niet vernietigd, maar ontbonden. Is in de beëindigingsovereenkomst zelf opgenomen dat het ontslag op staande voet wordt ingetrokken na het verstrijken van de bedenktermijn, of dat intrekken geschiedt onder de voorwaarde dat van de bedenktermijn geen gebruik is gemaakt, dan is een aparte verklaring niet nodig. De formulering van de voorwaarde waaronder het ontslag op staande voet wordt ingetrokken is dus relevant. In de praktijk zal de intrekking van het ontslag op staande voet ofwel impliciet gebeuren ofwel in een apart document zijn opgenomen en niet in de beëindigingsovereenkomst zelf. Een verwijzing naar een ontslag op staande voet in de beëindigingsovereenkomst kan immers een alarmfunctie hebben bij het aanvragen van een werk-

51. Vgl. H.N. Schelhaas, 'Lex imperfecta: schriftelijk = elektronisch, maar niet altijd', NTBR 2010/28 en de aldaar in voetnoot 3 genoemde literatuur. Schelhaas wijst er terecht op dat de wetgever verwarring heeft geschept door niet expliciet te zijn over het gelijkstellen van schriftelijk aan elektronisch.

52. Ktr. Leiden 1 juni 2016, ECLI:NL:RBDHA:2016:8371, r.o. 5.6. De rechtbank doelt op de uitspraak van Ktr. Amsterdam 10 juni 2015, ECLI:NL:RBAMS:2015:3968 waarin dit is bepaald.

53. HR 30 juni 1995, JAR 1995/152 en HR 16 februari 1979, NJ 1979/454. 
loosheidsuitkering. In dat geval is het de vraag of de ontbinding door de werknemer ook de intrekking van de opzegging raakt of dat die intrekking apart ongedaan moet worden gemaakt. Ook hier geldt dat de formulering van belang is als sprake is van een apart document.

Er zijn nog meer gevallen rondom het ontslag op staande voet denkbaar. Zo kan in een ontslag-op-staandevoetsituatie de werkgever ervoor kiezen de werknemer een beëindigingovereenkomst aan te bieden in plaats van hem op staande voet te ontslaan. Maakt de werknemer gebruik van de bedenktermijn dan is het de vraag of de werkgever alsnog op staande voet kan ontslaan of dat inmiddels geen sprake meer is van onverwijldheid. Met Sagel $^{54}$ menen wij dat de werkgever in dit geval op staande voet zou moeten kunnen ontslaan. De 'vertraging' is niet het gevolg van weinig voortvarend handelen van de werkgever, maar van een wettelijke termijn. Een onmiddellijk na het inroepen van de bedenktermijn gegeven ontslag op staande voet zou dus in ieder geval niet op de onverwijldheid moeten stranden.

\subsection{Casus 2}

Een andere situatie die regelmatig voorkomt is dat een ontbindingsverzoek wordt ingediend en bij gelegenheid van de mondelinge behandeling partijen 'op de gang' een schikking treffen. Partijen kunnen dit op verschillende manieren vormgeven: (i) het verzoekschrift kan worden ingetrokken en partijen sluiten alsnog een beëindigingsovereenkomst of (ii) partijen vragen de rechter een ontbindingsbeschikking af te geven en regelen eventuele openstaande punten in een aparte overeenkomst. ${ }^{55}$ In het eerste geval staat de werkgever met lege handen als de werknemer de beëindigingsovereenkomst ontbindt. Het verzoekschrift is immers ingetrokken en de werkgever zal dat opnieuw moeten indienen. Verstandiger is het de behandeling van het verzoekschrift aan te houden totdat de bedenktermijn is verstreken. Dit gebeurt in de praktijk wel. ${ }^{56}$ De tweede variant is interessanter. Als de rechter de ontbinding uitspreekt, dan is de arbeidsovereenkomst dus niet geëindigd door wederzijds goedvinden maar door rechterlijke ontbinding. De werknemer kan die beschikking niet ongedaan maken door van zijn bedenktermijn gebruik te maken, hij kan hooguit in hoger beroep. De 'losse-eindjes-overeenkomst' ${ }^{57}$ ziet dan bijvoorbeeld op het aantal vakantiedagen dat werknemer nog krijgt uitbetaald, op het concurrentiebeding en wellicht ook op een billijke vergoeding. ${ }^{58}$ Op die overeenkomst is de bedenktermijn niet

54. S.F. Sagel, 'Het ontslag op staande voet en de Wwz (I)', TRA 2015/45, p. 6-8, met de nodige nuances en varianten.

55. Deze mogelijkheid is expliciet door de wetgever erkend: Kamerstukken // 2013/14, 33818, 3, p. 103.

56. Zie bijvoorbeeld Hof Den Haag 9 januari 2016, ECLI:NL:GHDHA: 2016:47.

57. Zie over de losse-eindjes-overeenkomst ook Verburg t.a.p.

58. Dat zal niet altijd in de ontbindingsbeschikking kunnen worden opgenomen. Om toe te komen aan een billijke vergoeding zal de rechter immers moeten vaststellen dat de werkgever ernstig verwijtbaar heeft gehandeld. De werkgever die op zichzelf bereid is een billijke vergoeding te betalen zal dat niet snel opgenomen willen zien in een beschikking. van toepassing. ${ }^{59}$ Iets anders is de situatie dat de beëindiging met wederzijds goedvinden in één document is geregeld en overige voorwaarden in een andere overeenkomst (de losse-eindjes-overeenkomst). Boot c.s. beschrijven deze situatie en komen tot de conclusie dat in dat geval die tweede overeenkomst niet door de ontbinding wordt getroffen. ${ }^{60}$ Dat ligt onzes inziens genuanceerder. Het is geen constitutief vereiste dat een overeenkomst in één document is vastgelegd. ${ }^{61} \mathrm{Als}$ bedingen voldoende samenhang vertonen, kan sprake zijn van één overeenkomst, ook al is sprake van bedingen die in verschillende documenten zijn opgenomen. Afspraken die samenhangen met de beëindiging met wederzijds goedvinden zijn hiervan bij uitstek een voorbeeld.

\section{Conclusie}

Om te bepalen wanneer de bedenktermijn aanvangt, is van belang vast te stellen wanneer de beëindigingsovereenkomst tot stand is gekomen. Dat moment is, zoals Rechtbank Den Haag en Rechtbank Zeeland-West-Brabant terecht hebben geoordeeld, als een aanbod tot het aangaan van de beëindigingsovereenkomst schriftelijk is aanvaard. Van schriftelijke aanvaarding is sprake als in een geschrift (waaronder begrepen een e-mailbericht of elk ander elektronisch bericht dat voldoet aan de vereisten van artikel 6:227a BW) het aanbod wordt aanvaard. Het geschrift hoeft niet ondertekend te zijn. Ditzelfde geldt als een collectief aanbod schriftelijk wordt aanvaard. Er hoeft geen onderhandse akte (een door beide partijen ondertekend document) te zijn. Dit volgt uit de betekenis van 'schriftelijk' in het algemene vermogensrecht en het arbeidsrecht. De ratio van het schriftelijkheidsvereiste uit artikel 7:670b BW is met name gelegen in de rechtszekerheid. De ratio is niet zozeer de waarborgfunctie, zoals dat wel het geval is bij de schriftelijkheidseis van het concurrentiebeding. De waarborgfunctie wordt bij het aangaan van de beëindigingsovereenkomst immers vervuld door de bedenktermijn en niet door het schriftelijkheidsvereiste.

Hoewel op dit punt geen grote problemen lijken te bestaan, constateren wij dat een duidelijker startmoment van de bedenktermijn voor de praktijk praktischer was geweest. De vraag wanneer een aanbod is aanvaard en leidt tot de totstandkoming van de beëindigingovereenkomst is afhankelijk van de feitelijke situatie niet altijd eenduidig vast te stellen. Minst genomen kunnen partijen daarover van mening verschillen. Een objectief bepaald moment (bijvoorbeeld de ondertekening), zoals het geval is bij sommige andere bedenktermijnen, was duidelijker geweest.

59. Kamerstukken // 2013/14, 33818, 3. p. 103

60. G.C. Boot e.a. (red.), Arbeidsprocesrecht inclusief Wet werk en zekerheid', Deventer: Kluwer 2015, p. 15.

61. Zie A.G. Castermans en H.B. Krans, 'Gemengde overeenkomsten', NbBW 2003-7/8, p. 105. 
In de afgelopen decennia is meermaals de plaats van het arbeidsovereenkomstenrecht in het BW bediscussieerd. Voorstanders menen dat het algemeen verbintenissenen overeenkomstenrecht primair de grondslag is waarop het arbeidsrecht is gebouwd en dat de arbeidsovereenkomst om die reden in het BW thuishoort. Tegenstanders vinden dat deze er niet in thuishoort vanwege de zeggenschap die de werkgever over de werknemer heeft. De arbeid dient persoonlijk en op aanwijzing te worden verricht. Dit staat haaks op de obligatoire overeenkomst, waarbij iedere partij zelfstandigheid heeft. Het arbeidsrecht zou daarom een geheel eigen regeling moeten krijgen. Waar voor- en tegenstanders het wel over eens zijn, is dat het arbeidsovereenkomstenrecht grotendeels gaat over de niet gelijkwaardige verhouding tussen partijen en dat de algemene vermogens- en verbintenisrechtelijke regels in het $\mathrm{BW}$ de specifieke regels ter bescherming van de werknemer niet belemmeren. Sterker, ze geven de werknemer soms extra waarborgen. ${ }^{62}$ Het introduceren van de schriftelijkheidseis en de bedenktermijn maakt duidelijk dat bij de beoefening van het arbeidsrecht kennis van het algemene vermogensrecht nodig en nuttig is. 